Note

\title{
ANTIBIOTIC RESISTENCE OF Aeromonas hydrophila ISOLATED FROM Piaractus mesopotamicus (Holmberg, 1887) AND Oreochromis niloticus (Linnaeus, 1758)
}

\author{
Andréa Belém-Costa ${ }^{1}$; José Eurico Possebon Cyrino ${ }^{2 *}$ \\ ${ }^{I}$ UFAM - Centro de Apoio Multidisciplinar - Divisão de Biotecnologia, Av. Rodrigo Otávio, 3000 - 69077-900 - \\ Manaus, AM - Brasil. \\ ${ }^{2}$ USP/ESALQ - Depto. de Zootecnia - Setor de Piscicultura, C.P. 09 - 13418-900 - Piracicaba, SP - Brasil. \\ *Corresponding author <jepcyrin@esalq.usp.br>
}

\begin{abstract}
One of the most important problems involving treatments with antibiotics against Aeromonas hydrophila isolated from fishes is that antibiotic resistance develops readily. The antimicrobial activity of chemotherapeutants in isolates from pacu Piaractus mesopotamicus (Holmberg, 1887) and tilapia Oreochromis niloticus (Linnaeus, 1758) was tested by the Kirby-Bauer disk method, over Mueller-Hinton surface agar previously inoculated with $100 \mu \mathrm{L}$ of bacterial suspensions. After regular incubation, isolates from tilapia and pacu were uniformly resistant to amoxicillin, ampicillin, lincomycin, novobiocin, oxacillin, penicillin, and trimetoprim+sulfametoxazole. The $A$. hydrophila type strain presented resistance to the same antimicrobial substances and also against rifampicin; the bacterial isolate from pacu were the only strain resistant to tetracyclin. Isolates from both pacu and tilapia had intermediate reaction with erytromycin. The use of drugs in commercial fish farms in Brazil can favor the development of resistant bacterial strains in native fish species as already observed for exotic species, commercially produced for longer time.
\end{abstract}

Key words: bacterial isolates, bacterial strains, antimicrobial substances, chemotherapeutants, drugs

\section{RESISTÊNCIA DE Aeromonas hydrophila ISOLADA DE Piaractus mesopotamicus (Holmberg, 1887) E Oreochromis niloticus (Linnaeus, 1758) A ANTIBIÓTICOS}

\begin{abstract}
RESUMO: Um dos maiores problemas envolvendo o tratamento com antibióticos contra Aeromonas hydrophila isolada de peixes confinados é a rápida resistência ao antibiótico desenvolvida pela bactéria. A atividade antimicrobiana de quimioterapêuticos em isolados a partir de pacu Piaractus mesopotamicus (Holmberg, 1887) e tilápia Oreochromis niloticus (Linnaeus, 1758) foi verificada pelo método de difusão de antibiótico em discos de Kirby-Bauer, sobre uma superfície de Agar Mueller-Hinton previamente inoculada com $100 \mu \mathrm{L}$ de suspensão bacteriana. Após o período de incubação, os isolados de tilápia e pacu foram uniformemente resistentes a amoxicilina, ampicilina, lincomicina, novobiocina, oxacilina, penicilina e trimetoprim+sulfametoxazol. A cepa tipo para $A$. hydrophila apresentou resistência às mesmas substâncias antimicrobianas e também contra a rifampicina; o isolado bacteriano de pacu foi a única linhagem resistente a tetraciclina. Isolados de pacu e tilápia apresentaram resistência intermediária frente a eritromicina. $\mathrm{O}$ uso de medicamentos em pisciculturas comerciais no Brasil pode favorecer o desenvolvimento de linhagens bacterianas resistentes em espécies de peixes nativos, como já observado em espécies exóticas comercialmente produzidas há mais tempo.

Palavras-chave: isolados bacteríanos, cepas bacteríanas, antimicrobianas, quimioterapêuticos, drogas
\end{abstract}

\section{INTRODUCTION}

Intensification of fish farming in Brazil has increased the number of disease outbreaks in intensive production systems. Most etiological agents were not yet identified and their morbid processes still not studied. The Aeromonas complex are important fish patho- genic bacteria, causing septicemic infections and associated economic losses in fish culture worldwide (Holliman, 1993).

Multiple antibiotic resistance (MAR) has been registered for Aeromonas hydrophila isolated from freshwater fish farms in association with a variety of drugs, commonly used as feed additives (Aoki et al., 
1971; Pettibone et al., 1996; Son et al., 1997; Vivekanandhan et al., 2002). The main problem involving the use of antibiotics against Aeromonas infections is the development of resistance by these bacteria (Aoki \& Egusa, 1971; Mitchell \& Plumb, 1980), generally related to the presence of plasmids (Chang \& Bolton, 1987; Ansary et al., 1992).

This work aims to identify antibiotic-resistant Aeromonas strains isolated from pacu Piaractus mesopotamicus and Nile tilapia Oreochromis niloticus, in intensive farming systems in South East Brazil.

\section{MATERIAL AND METHODS}

The antimicrobial activity of $A$. hydrophila isolates from pacu (LQUSP22) and tilapia (LQUSP15), collected during disease outbreaks in fish farms in Piracicaba $\left(22^{\circ} 41^{\prime} 15^{\prime \prime} \mathrm{S} ; 4^{\circ} 41^{\prime} 15^{\prime \prime} \mathrm{W}\right)$ and Jaú $\left(22^{\circ} 18^{\prime} 45^{\prime \prime} \mathrm{S} ; 48^{\circ} 33^{\prime} 45^{\prime \prime} \mathrm{W}\right)$, State of Sao Paulo, Brazil, and of the A. hydrophila type strain (ATCC7966), from the American Type Culture Collection, were compared by growth inhibition by the disk-agar diffusion method on Mueller-Hinton Agar (Merck ${ }^{\circledR}$ ), as recommended by Stukus (1997). Both isolates were identified through biochemical methods and preserved in liquid nitrogen until use.

The following commercial disks antimicrobial substances used were: amoxicillin $(25 \mu \mathrm{g})$; ampicillin $(10 \mu \mathrm{g})$; chloramphenicol $(30 \mu \mathrm{g})$; erythromycin (15 $\mu \mathrm{g})$; gentamicin $(10 \mu \mathrm{g})$; kanamycin $(30 \mu \mathrm{g})$; lincomycin $(2 \mu \mathrm{g})$; nitrofurantoin $(300 \mu \mathrm{g})$; norfloxacin $(10 \mu \mathrm{g})$; novobiocin $(30 \mu \mathrm{g})$; oxacillin $(1 \mu \mathrm{g})$; penicillin $\mathrm{G}(10$ $\mathrm{U}=6 \mu \mathrm{g})$; rifampicin $(5 \mu \mathrm{g})$; streptomycin $(10 \mu \mathrm{g})$; sulbactam $(10 \mu \mathrm{g})+$ ampicillin $(10 \mu \mathrm{g})$; tetracycline $(30$ $\mu \mathrm{g})$; and trimethoprim $(1.25 \mu \mathrm{g})+$ sulphamethoxazole $(23.75 \mu \mathrm{g})$. All tested antibiotics are ordinarily used in human medicine (Rhodes et al., 2000; MacMillan, 2001; Holmström at al., 2003). The commercial disks carrying small volumes of highly concentrated drugs provide a method of rapid diagnostic in which antibiotics serve as selective agents (Holt \& Krieg, 1994).

Disks were spreaded over the surface of the agar, previously inoculated with $100 \mu \mathrm{L}$ of suspensions of the test organisms prepared in Yeast Extract broth at $28^{\circ} \mathrm{C}$ for $24 \mathrm{~h}$ (Costa et al., 1998). After overnight incubation at $28^{\circ} \mathrm{C}$, the zone of inhibition was measured $(\mathrm{mm})$, and calculations of zone diameter breakpoints, corresponding to limits of NCCLS - National Committee for Clinical Laboratory Standards (Cooper, 1955; Kronvall, 1982), were done.

\section{RESULTS AND DISCUSSION}

The isolates from tilapia and pacu were all resistant to amoxicillin, ampicillin, lincomycin, novobiocin, oxacillin, penicillin, and trimetoprim + sulfametoxazole. The A. hydrophila type strain, presented resistance to the same antimicrobial substances, and also against rifampicin; the bacterial isolates from pacu were also resistant to tetracyclin. The bacterial isolate from pacu and the A. hydrophila type strain had intermediate reaction with erytromycin (Table 1).

Table 1 - Susceptibility/Resistance profiles of bacteria isolated from fish and A. hydrophila (ATCC7966) type strain used in the present study. R-resistant; S-susceptible; I-intermediate.

\begin{tabular}{lccc}
\hline ANTIBIOTICS & LQUSP22 (PACU) & LQUSP15 (TILAPIA) & ATCC7966 \\
\hline amoxicillin, $25 \mu \mathrm{g}$ & $\mathrm{R}$ & $\mathrm{R}$ & $\mathrm{R}$ \\
ampicillin, $10 \mu \mathrm{g}$ & $\mathrm{R}$ & $\mathrm{R}$ & $\mathrm{R}$ \\
chloramphenicol, $30 \mu \mathrm{g}$ & $\mathrm{S}$ & $\mathrm{S}$ & $\mathrm{S}$ \\
erytromycin, $15 \mu \mathrm{g}$ & $\mathrm{I}$ & $\mathrm{S}$ & $\mathrm{I}$ \\
gentamicin, $10 \mu \mathrm{g}$ & $\mathrm{S}$ & $\mathrm{S}$ & $\mathrm{S}$ \\
kanamycin, $30 \mu \mathrm{g}$ & $\mathrm{S}$ & $\mathrm{S}$ & $\mathrm{S}$ \\
lincomycin, $2 \mu \mathrm{g}$ & $\mathrm{R}$ & $\mathrm{R}$ & $\mathrm{R}$ \\
nitrofurantoin, $300 \mu \mathrm{g}$ & $\mathrm{S}$ & $\mathrm{S}$ & $\mathrm{S}$ \\
norfloxacin, $10 \mu \mathrm{g}$ & $\mathrm{S}$ & $\mathrm{S}$ & $\mathrm{S}$ \\
novobiocin, $30 \mu \mathrm{g}$ & $\mathrm{R}$ & $\mathrm{R}$ & $\mathrm{R}$ \\
oxacillin, $1 \mu \mathrm{g}$ & $\mathrm{R}$ & $\mathrm{R}$ & $\mathrm{R}$ \\
penicillin $\mathrm{G}, 6 \mu \mathrm{g}$ & $\mathrm{R}$ & $\mathrm{R}$ & $\mathrm{R}$ \\
rifampicin, $5 \mu \mathrm{g}$ & $\mathrm{S}$ & $\mathrm{S}$ & $\mathrm{R}$ \\
streptomycin, $10 \mu \mathrm{g}$ & $\mathrm{S}$ & $\mathrm{S}$ & $\mathrm{S}$ \\
sulbactam + ampicillin, $10 \mu \mathrm{g}+10 \mu \mathrm{g}$ & $\mathrm{R}$ & $\mathrm{R}$ \\
tetracycline, $30 \mu \mathrm{g}$ & $\mathrm{R}$ & $\mathrm{S}$ & $\mathrm{S}$ \\
trimethoprim + sulphamethoxazole, $1.25 \mu \mathrm{g}+23.75 \mu \mathrm{g}$ & $\mathrm{S}$ & $\mathrm{S}$ & $\mathrm{S}$ \\
\hline
\end{tabular}

LQUSP = Luiz de Queiroz, Universidade de São Paulo. 
The motile Aeromonas group is responsible for severe fish diseases, such as hemorrhagic septicemia (Bullock et al., 1971; Egusa, 1978; Schäperclaus et al., 1992) and ulcerative disease of fish (Karunasagar et al., 1995). The worldwide distribution of this group is a consequence of its great adaptability to different aquatic environments (Mateos et al., 1993). Infections by Aeromonas had been observed in various freshwater fish species and eventually in marine fish, reptile, bovine, and man (Bullock et al., 1971; Khardori \& Fainstein, 1988). MAR has been recorded for several A. hydrophila strains around the world (Pettibone at al., 1996; Son et al., 1997). However, cumulative effects of chemotherapeutants on the environment and on the bacterial ecology of farmed fish have received little attention (DePaola et al., 1995).

The extensive use of antibiotics and other chemotherapeutants in fish farms, either to prevent or cure fish diseases, both as feed additives or dissolved directly into the water, has resulted in increasing antibiotic resistance among pathogenic bacteria. The bacterial isolate from pacu was resistante to eight out of the seventeen antibiotics tested, and the isolated from tilapia presented resistance against seven antimicrobial substances. The reference strain showed resistance to seven of eight antimicrobial substances to which the isolate of the Brazilian-native pacu was also resistant, and also to rifampicin.

The isolate from pacu was the only strain that presented resistance against tetracycline. Apparently, the most common antibiotic, indiscriminately used by Brazilian fish farmers, have already given rise to resistant bacterial strains affecting native fish species which have been produced commercially for no longer than a decade. Therefore, controlled, in-depth studies are needed to determine the effect of antimicrobial therapy on the microbial ecology of cultured fishes in Brazil.

According to Adams et al. (1998) and Rhodes et al. (2000), the aquaculture is related to the presence of bacterial resistant strains in a manner that interactive relationships between two different compartments, like hospitals and fish farms, can be though off. Based on the plasmid distribution into the Aeromonas group, these places behave in a reciprocal way. It is therefore important to investigate the use of antibiotics in aquaculture, the associated resistance to other relevant bacteria, and broaden the research to other geographic regions and other fish pathogens.

Because of the negative economic impact of disease outbreaks, and the fact that infections by $A$. hydrophila are most significant in warm water fisheries and aquaculture, it would be very important to study the virulence of $A$. hydrophila, their resistant plasmid transference, and hability to adhere and infect other Brazilian-native fish. Understanding the role of different motile Aeromonas species in tropical fish disease will provide information leading to adequate prophylactic practices, and development of new drugs to be used in the Brazilian aquaculture.

\section{ACKNOWLEDGEMENT}

To Fundação de Amparo à Pesquisa do Estado de São Paulo (Sao Paulo State Research Foundation FAPESP) for the grant-in-aid (99/12892-4) and the scholarship to Dr. A.B. Costa (99/00414-0).

\section{REFERENCES}

ADAMS, C.A.; AUstin, B.; MEAden, P.G.; McInTOSH, D. Molecular characterization of plasmid-mediated oxytetracycline resistance in Aeromonas salmonicida. Applied and Environmental Microbiology, v.64, p.4194-4201, 1998.

ANSARY, A.; HANEEF, R.M.; TORRES, J.L.; YADAV, M. Plasmids and antibiotic resistance in $A$. hydrophila. Journal of Fish Biology, v.15, p.191-196, 1992.

AOKI, T.; EGUSA, S. Drug sensitivity of Aeromonas liquefaciens isolated from freshwater fishes. Bulletim of the Japanese Society for Scientific Fisheries, v.37, p.176-185, 1971.

AOKI, T.; EGUSA, S.; OGATA, Y.; WATANABE, T. Detection of resistance factors in fish pathogen Aeromonas liquefaciens. Journal of General Microbiology, v.65, p.343-349, 1971.

BULLOCK, G.L.; CONROY, D.A.; SNIESKO, S.F. Septicemic diseases caused by motile aeromonads and pseudomonads. In: SNIESKO, S.F.; AXELROD, H.R. (Ed.) Diseases of fishes. Neptune:T.F.H. Publ., 1971. v.2A, p.21-41: Bacterial diseases of fishes.

CHANG, B.J.; BOLTON, S.M. Adherence haemagglutination and cell surface characteristics of motile aeromonads virulent for fish. Journal of Fish Diseases, v.13, p.255-268, 1987.

COOPER, K.E. Theory of antibiotic inhibition zones in agar media. Nature, v.176, p.510-511, 1955.

COSTA, A.B.; KANAI, K.; YOshiKOSHI, K. Serological characterization of atypical strains of Edwardsiella tarda isolated from SeaBream. Fish Pathology, v.33, p.265-274, 1998.

DePAOLA, A.; PEELER, J.T.; RODRICK, G.E. Effect of oxytetracycline-medicated feed on antibiotic resistance of Gramnegative bacteria in catfish ponds. Applied and Environmental Microbiology, v.61, p.2335-2340, 1995.

EGUSA, S. Infectious diseases of fish. Tokyo: Kouseisha Kouseikaku, 1978. 554p.

HOLLIMAN, A. The veterinary approach to trout. In: BROWN, L. (Ed.). Aquaculture for veterinarians: fish husbandry and medicine. Oxford: Pergamon Press, 1993. cap.14, p.223-247.

HOLMSTRÖM, K.; GRÄSLUND, S.; WAHLSTRÖM, A.; POUNGSHOMPOO, S.; BENGTSSON, B.; KAUTSKY, N. Antibiotic use in shrimp farming and implications for environmental impacts and human health. International Journal of Food Science and Technology, v.38, p.255, 2003.

HOLT, J.G.; KRIEG, N.R. Enrichment and isolation. In: GERHARDT, P.; MURRAY, R.G.E.; WOOD, W.A.; KRIEG, N.R. Methods for general and molecular bacteriology. Washington: American Society for Microbiology, 1994. cap.8, p.179-215.

KARUNASAGAR, I.; SUGUMAR, G.; KARUNASAGAR, I. Virulence characters of Aeromonas sp. isolated from EUS-affected fish. In: SHARIF, M.; ARTHUR J.R.; SUBASINGHE, R.P. (Ed.). Diseases in Asian aquaculture II. Manila: Asian Fisheries Society, Fish Health Section, 1995. p.307-314. 
KHARDORI, N.; FAINSTEIN, V. Aeromonas and Plesiomonas as etiological agents. Annual Review of Microbiology, v.42, p.395419, 1988.

KRONVALL, G. Analysis of a single reference strain for determination of gentamicin regression line constants and inhibition zone diameter breakpoints in quality control of disk diffusion antibiotic susceptibility testing. Journal of Clinical Microbiology, v.16, p.784793, 1982.

MACMILLAN, J.R. Aquaculture and antibiotic resistance: A negligible public health risk? World Aquaculture, v.32, p.49-50, 2001.

MATEOS, D.; ANGUITA, J.; NAHARRO, G.; PANIAGUA, C. Influence of growth temperature on the production of extracellular virulence factors and pathogenicity of environmental and human strains of Aeromonas hydrophila. Journal of Applied Bacteriology, v.74, p.111-118, 1993.

MITCHELL, A.J.; PLUMB, J.E. Toxity and efficacy of Furanace on channel catfish infected experimentally with Aeromonas hydrophila. Journal of Fish Diseases, v.3, p.93-100, 1980.

PETTIBONE, G.W.; MEAR, J.P.; SAMPSELL, B.M. Incidence of antibiotic and metal resistance and plasmid carriage in Aeromonas isolated from brown nullhead (Ictalurus nebulosus). Letters in Applied Microbiology, v.23, p.234-240, 1996.

RHODES, G.; HUYS, G.; SWINGS, J.; McGANN, P.; HINEY, M.; SMIYH, P.; PICKUP, R.W. Distribution of oxytetracycline resistance plasmids between Aeromonads in hospital and aquaculture environments: Implication of $\mathrm{Tn} 1721$ in dissemination of the tetracycline resistance determinant Tet A. Applied and Environmental Microbiology, v.66, p.3883-3890, 2000.
SCHÄPERCLAUS, W.; KULOW, H.; SCHRECKEBACH, K. Infectious abdominal dropsy. In: SCHÄPERCLAUS, W. (Ed.). Fish diseases. Berlin: AkademieVerlag, 1992. v.1, p.401-458.

SON, R.; RUSUL, G.; SAHILAH, A.M.; ZAINURI, A.; RAHA, A.R.; SALMAH, I. Antibiotic resistance and plasmid profile of Aeromonas hydrophila isolates from cultured fish, Telapia (Telapia mossambica). Letters in Applied Microbiology, v.24, p.479-482, 1997.

STUKUS, P.E. Antimicobial testing. The Kirby-Bauer method (filterpaper disk method). In: STUKUS, P.E. (Ed.). Investigating microbiology: a laboratory manual for general microbiology. Orlando: Harcourt Brace \& Company, 1997. cap.44, p.243-247.

VIVEKANANDHAN, G.; SAVITHAMANI, K.; HATHA, A.A.M.; LAKSHMANAPERUMALSAMY, P. Antibiotic resistance of Aeromonas hydrophila isolated from marketed fish and prawn of South India. International Journal of Food Microbiology, v.76, p.165-168, 2002.

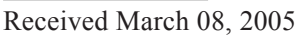

Accepted March 31, 2006 